\title{
Reading Homer's The Iliad in 21st Century
}

\author{
Mafruha Ferdous \\ Northern University, Bangladesh \\ E-mail: mafruhaferdous@yahoo.com
}

Doi:10.7575/aiac.alls.v.8n.2p.101

Received: 27/02/2017

URL: http://dx.doi.org/10.7575/aiac.alls.v.8n.2p.101

Accepted: 24/04/2017

\begin{abstract}
Homer's Iliad refers to an epic story written by the ancient Greek poet Homer, which makes an account of the most significant events that earmarked the very last days which defined the Trojan War and the Greek siege of the city of Troy. Troy was also known as Ilium, Ilion, or Ilois in the past. Having made to center around the events of the Trojan War, Homer's Iliad is a work of art that paints to all of us interested in literature, what really happened in the past. The paper purposes to provide invaluable insights regarding the significance of Homer's Iliad today and what it teaches us about poetry and the ancient culture of the Greeks.
\end{abstract}

Keywords: Homer, Iliad, Greece

\section{Introduction}

Homer's Iliad is still appreciated in the 21st century despite the fact that they were composed for listeners and readers approximately 3000 years ago. The poems that constitute Homer's Iliad were, also, heir to a longstanding tradition of oral poetry that produced many other similar compositions, which at the moment stand as faded save for a number of fragments and late summaries of contents. It is also worth mentioning that the entirety of the Iliad composed by Homer helps all the modern day readers to understand the nature of oral composition i.e. conversational syntax and the utilization of formulas.

For the audiences interested in reading the Iliad there is a need to know that this work of art sources the initial syllables of the title designate from Ilion (which in Greek it means Troy) or, in other words, the name Ilium (Latin for Troy). The suffix-ad means; related to, or being related with. Therefore, the Iliad refers to a story about Troy (McLuhan and Bruce, 63)

Upon reading the works of Homer, enthusiasts in the 21st century realize the relevance of this talented writer to Ancient Greek History and modern day audiences. An example of how works of Homer have been appreciated in the course of time up until today is through theater and film; the motion picture film "Troy" centers its entire plot on Homer's Iliad. On a much more personal level, it is my opinion that no other texts or works of poetry in the western world and imagination occupy as central a position in the self-definition of Western culture as the two legendary poems of Homer, the Iliad being most pronounced. These are perfect masterpieces that both concern the best defining moments of the Greek culture, the Trojan War (Wilner, Ennis and Richard, 67)

Reading Homer's Iliad in 21st Century makes one realize that the poem's setting is about 3200 years in the infancy of recorded history. It was during a moment when the imagination of human beings occupied the recognized world with great villains and heroes and the nature illustratedthe moods of the gods that were present in the oceans, the woodlands, the mountain tops, and the imagined sections of the cosmos. Homer structured his stories, particularly the Iliad, approximately six centuries after the end of the war. The stories and poems within Homer's works revolve around legend, fact, and myth (Jenkins et al., 37)

Historical Troy was proven to be existent after a series of archaeological digs between the years 1870 and 1890 by Heinrich Schliemann. Schliemann was a German-born American archeologistwho focused on making the existence of Troy evident and that the story of the ancient city is based on fact rather than a myth as most people perceived. All the same, the story of the Trojan War as illustrated by Homer was passed on from generation to generation as a blend of facts, and myths.

\section{Homer's Importance Today}

The Iliad is among the topmost influential and significant pieces of literature in modern day poetry. It gets this status because it made an establishment of literary ideals and frameworks that most writers have and are imitating since the time of old and even today. Homer's works had also brought about archetypes that several great hundred writers including Dante, Vergil, Stephen Crane, Shakespeare, and James Joyce indicated to when they required an apt simile or metaphor. What's more, Homer's works have been able to present a myriad of significant information regarding Greek ideals and customs and Hellenistic mythology. Homer is truly an accomplished writer; a legend that, despite not having a literary model to juxtapose his work upon, he was able to present a chef-d'oeuvre that is placed among the greatest works. Homer's work cannot be ignored by literature students and that no author's education is fulfilled unless he goes through Homer (Wells and Guy, 12). 


\section{Verse Format in Homer's Poems}

The meter of Homer's legendary poems can be described as dactylic hexameter. A dactyl refers to a metrical foot that contains of a single accented syllable succeeded by two syllables that are unaccented; good examples are the wordsharbinger (HAR bin jer), technical (TEK nik 1), and allocate (AL oh Kate) while a hexameter refers to a line that contains six metrical feet. Therefore, a dactylic hexameter refers to a scheme that is made up of six dactyls. The following line illustrates a good example of the dactylic hexameter: MAKE me a HAT fringed with TASS les DOWN and a BEAU ti ful GOWN, good madam (FAUL and Maureen, 83).

\section{Homeric Epithet}

The appellation or the epithet is among the unique features of the Homeric stylishness which entails a mix of a noun and anexpressive phrase. What a Homeric epithet does is that it brings forward a small painting that makes an identification of an individual or any feature where it makes a highlight of a common anddistinctiveaspect of that item or individual. In the English language, the epithet is normally made up of a compound adjective and a noun. Good examples include; "rosy-fingered dawn", "fleet-footed Achilles", "wine-dark sea", "gray-eyed Athena", and "earth-shaking Poseidon" (Hernandez, 6). Today it is evident that the epithet is a past relation of epithets that came later that include Ivan the Terrible, Richard the Lion-Hearted, and America the Beautiful. Homer made repetitions of his epithets now and then, in all probability so the audiences of his narratedstories could easily comprehend and recall the individual or phenomenon being talked about in a much easier way every time they were mentioned. With respect to this point of view, the appellation is a reflection of the leitmotiv of Richard Wagner who was a poet. The leitmotiv was amelodious theme that was repetitive in nature and was linked with a group, character, or afeeling.

\section{Attitude toward the Afterlife}

After reading the works of Homer, we in the 21 st century get to understand that the "here and now" concerns of the Greeks defined in this famed writer's Iliad surpass their concerns of the afterlife; this is because they generally had a belief that the home of the dead is dismal and dark. As a result, their main aim in life was to realize immediate rewards and live for the moment (Arthur and Denise, 55) The notion of a better place i.e., heaven, that would have been capable of avenging them for good deeds, be it off or on the battlefield, was of less significance to them. All the same, we also learned that the Greeks revered the gods of Olympus, who took sides in the Trojan War; the people were afraid that offending the Gods would have caused their wrath and affected the result of the war.

\section{Epic Conventions Garnered}

The famous poet and playwright Homer made an establishment of literary rules, practices, or devices that became a very much common place in the epic poetry written much later on. The devices mentioned above or rules are at the moment known as epic conventions. They revolve around;

Telling a narrative with which listeners or readers are already accustomed to, they are aware of the story line, the characters, and the ending. Most of the famous playwrights and writers in the entire history of literature, Shakespeare included-oftentimes told of narratives that were already known by many. Therefore in such a manner of stories, there weren't any expected surprise endings or plot twists. If this revelation sounds a bit strange to readers and theatergoers of modern times; with that in mind, it is very much important to make a consideration of the fact that a variety of the renowned motion pictures of today revolve around stories that are already recognized well by people. Examples include the Titanic, The Passion of Christ, The Ten Commandments, Gettysburg, Spartacus, Pearl Harbor and most definite, Troy. Homer also painted a picture that there was a skirmish in the celestial world (Singer, 34).

Reading Homer's Iliad in the 21st century is evidence enough of what oral tradition is capable of that is, passing down information from one generation to the next irrespective of time and space. For example, the story revolving around the "death of Hector" makes modern day readers get to understand the cultures of the past, and what happened in the course of time. In a nutshell, the Iliad is a legendary and epic poem, an extended narrative work regarding heroic exploits that is pronounced in matters of the tome and highly formal in its language. For the most part, the Iliad was composed in ancient Greek and passed down orally before it was finally written down. Today many modern translators and literature lovers make a presentation of the Iliad in prose, making it read like a novel.

\section{References}

Arthur, Michael B., and Denise M. Rousseau. "A career lexicon for the 21st century." The Academy of Management Executive 10.4 (1996): 28-39.

FAUL, DENIS, and Maureen Alden. "HOMER BESIDE HIMSELF: Para-Narratives in the Iliad." (2002): $252-253$.

Hernandez, Pura Nieto. "Reading Homer in the 21st century." College Literature 34.2 (2007): 29-54.

Jenkins, Henry, et al. Confronting the challenges of participatory culture: Media education for the 21st century. Mit Press, 2009.

McLuhan, Marshall, and Bruce R. Powers. The global village: Transformations in world life and media in the 21st century. Oxford University Press, USA, 1989.

Singer, Peter Warren. Wired for war: The robotics revolution and conflict in the 21st century. Penguin, 2009.

Wells, Gordon, and Guy Claxton, eds. Learning for life in the 21st century: Sociocultural perspectives on the future of education. John Wiley \& Sons, 2008.

Wilner, Ortha L., Ennis Rees, and Richard John Cunliffe. "The" Iliad" of Homer." (1963): 382-383. 